\title{
Chromosomal analysis of the eggs and ovaries of the laying workers of Apis cerana $F$
}

\author{
S Verma, A Karol \\ Himachal Pradesh University, Department of Bio-Sciences, Summerhill, Shimla-171 005, HP India
}

(Received 18 March 1991; accepted 4 May 1992)

Summary - The chromosomal behavior during mitotic and meiotic cell division of eggs and ovaries of Apis cerana $F$ laying workers has been examined. The laying workers are diploid $(2 n=32)$, but undergo meiosis to produce drone brood which possesses a haploid $(n=16)$ set of chromosomes.

Apis cerana / meiosis / chromosome number / parthenogenesis / laying worker

\section{INTRODUCTION}

In a normal honey bee colony the worker bees and the queen bee are diploid females but the drones are haploid males. The ovaries of the queen bee are well developed and functional, whereas the ovaries of the worker bees are rudimentary structures and are non-functional.

A number of studies have reported the unusual occurrence in certain races of honey bees of impaternate females among the male progeny of virgin queens and laying workers. Among the different races of Apis mellifera $\mathrm{F}$ the phenomenon of female parthenogenesis is most remarkable in Apis mellifera capensis. Onion (1912) reported that worker bees in the queenless colonies of the capensis bee start developing ovaries and also possess a developed spermatheca which is devoid of any kind of sperm cells. Ruttner (1976) gave an detailed account of capensis taxonomy and concluded that the workers' ovaries possess a large number of ovarioles, that they were also surrounded by a 'court of bees', and that their brood was scattered on the comb. Ruttner obtained several generations of capensis worker bees without any kind of sexual mating and suggested that an automictic type of parthenogenesis took place. Later, Ruttner and Verma (1983) studied the actual cytological mechanisms of female parthenogenesis in this race of honey bees.

A similar phenomenon of female parthenogenesis has been observed in Apis cerana F (Tokuda, 1924; Akahira and Sakagami, 1958; Naim et al, 1985). However, no previous attempts have been made to study the cytological mecha- 
nisms involved in female parthenogenesis of this species of honey bees.

The aim of the present investigation was to make a detailed chromosomal analysis of the ovaries and eggs of the laying workers of Apis cerana $\mathrm{F}$ to determine how the arrhenotokous production of the drone brood by the laying worker bees takes place without any sexual mating.

\section{MATERIAL AND METHODS}

The laying workers of Apis cerana indica were obtained from the colonies kept at the Summerhill, Shimla apiary. They were observed about 2 weeks after dequeening. Up to 12 eggs were found per cell. The eggs were collected with a fine brush, and the ovaries and eggs were processed for chromosomal preparations. They were fixed in Carnoy's fixative (Darlington and LaCour, 1976). The squash preparations were stained in acetocarmine (Kitzmiller and Clerk, 1952). The photomicrographs were taken at 90 $x 10$ magnification.

\section{RESULTS}

Each of the 2 ovaries possesses 2-12 ovarioles with 4-5 developing follicles in each ovariole (fig 1). The mitotically dividing oogonial cells possess 32 chromosomes (fig 2). Some of the meiotic stages which were observed in the eggs clearly showed the pairing and recombination of chromosomes. In diakinesis and metaphase I (figs 3, 4), 16 bivalents were clearly counted. In anaphase I (fig 5), the 2 sets of chromosomes separated and moved towards opposite poles. The metaphase II stage of meiosis showed 16 (that is a haploid set) of chromosomes (fig 6). However, in some of the egg cells the number of bjvalents amounted to 8 (fig 7 ).

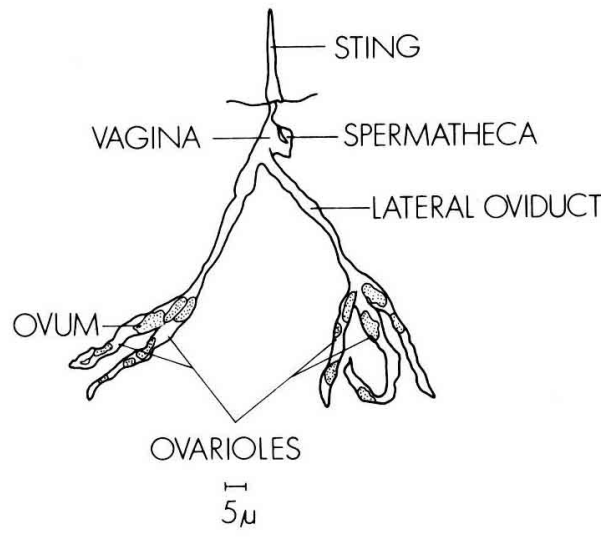

Fig 1. Reproductive system of the laying worker of Apis cerana indica (diagrammatic).

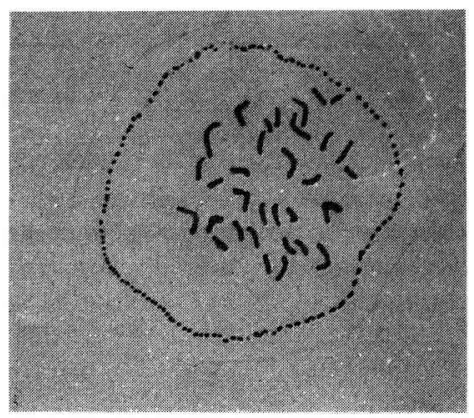

Fig 2. Oogonial metaphase $2 n=32$.

\section{DISCUSSION}

As in Apis mellifera capensis (Ruttner, 1976), Apis cerana indica also has laying workers (Toluda, 1924). In Apis cerana indica the laying worker bee possesses a pair of ovaries, each ovary consisting of 212 ovarioles with 4-5 developing ova in each ovariole. Kapil (1962) also reported the same number of ovarioles in the laying 


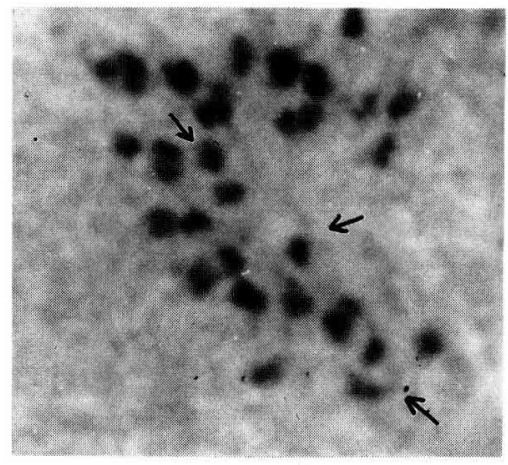

Fig 3. Diakinesis stage with 16 bivalents.

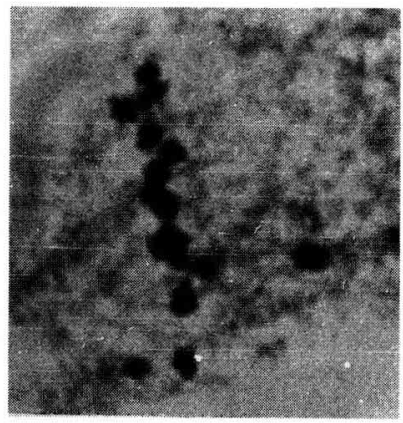

Fig 4. Metaphase I with 16 bivalents.

workers of this bee species. However, Sato et al (1984) observed 4-9 ovarioles in the ovaries of Apis cerana japonica laying workers.

The oogonial cells of the ovaries of the laying workers of Apis cerana indica have 32 chromosomes (fig 2), as reported in the queen bee and the other worker bees of this species (Fahrenhorst, 1977; Verma, 1988). The karyological study of the honey

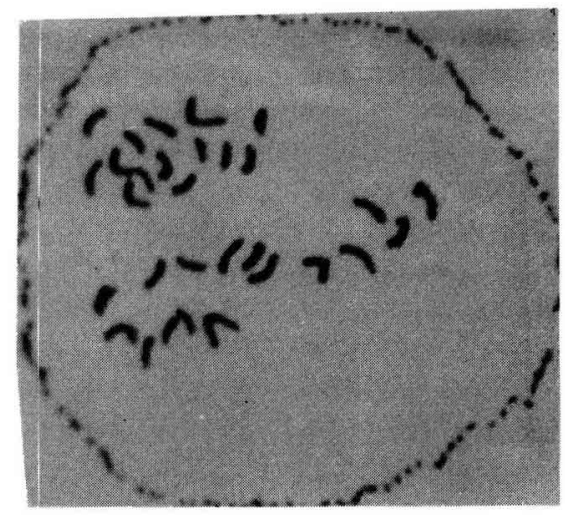

Fig 5. Anaphase I. 16 chromosomes moving towards the opposite poles.

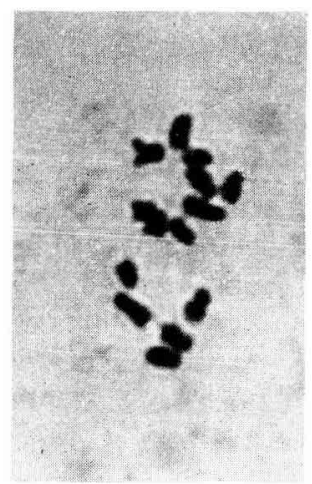

Fig 6. Metaphase II. $n=16$.

bee carried out by Hoshiba et al (1978) further supports this view.

The studies performed on the eggs and ovaries of the laying workers of this bee showed meiosis. In diakinesis and metaphase I (figs 3, 4) 16 bivalents were found. This showed the pairing and recombination of the somatic chromosomes like those of the laying workers of Apis mellifera capensis (Ruttner and Verma, 1983). The hap- 


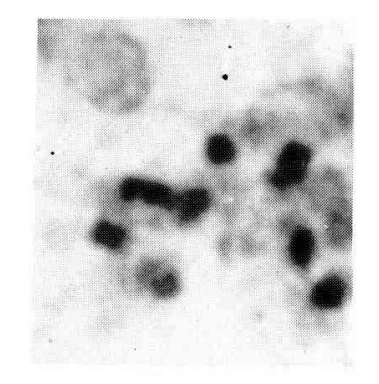

Fig 7. 8 Tetravalents.

loid set of chromosomes formed as a result of meiosis (fig 6) seems to form the drones chromosomal complement as such without any type of union because the same number of chromosomes have also been found in the drones.

The presence of 8 bivalents (fig 7), which have been found in many cells, is an unusual feature. This can be accounted for by the partial or incomplete pairing of the 16 bivalents to form tetravalents. A secondary chromosomal pairing has been reported during meiotic prophase in Apis mellifera (Nachtsheim, 1913) and in Apis mellifera ligustica (Kerr and Silveira, 1972).

The secondary pairing may be due to the homology among the somatic chromosomes. Deodikar and Thakar (1966) have reported the probable origin of $n=16$ from the 4 heterologous chromosomes, which may give rise to the homology of the somatic chromosomes. However, this fact needs further clarification.

\footnotetext{
Résumé - Analyse des chromosomes des cuufs et des ovaires des ouvrières pondeuses d'Apis cerana F. Les ouvrières pondeuses d'Apis cerana possèdent
}

une paire d'ovaires renfermant chacun 2 à 12 ovarioles (fig 1). Dans les préparations de chromosomes provenant des ovaires on a trouvé le nombre diploïde de chromosomes, $2 n=32$ (fig 2). Ce n'est que dans les œufs qu'on a trouvé diverses phases de la méiose. Aux stades diacinèse et métaphase I, on a observé 16 chromosomes bivalents (figs 3 et 4). La présence de bivalents montre qu'il existe un appariement et une nouvelle répartition des chromosomes homologues. À l'anaphase I (fig 5), les 2 ensembles de chromosomes, comprenant chacun 16 chromosomes, se déplacent en direction du pôle opposé. Au stade métaphase II (fig 6) on a également observé l'ensemble haploïde de $n=16$ chromosomes. Quelques cellules ne présentaient que 8 bivalents (fig 7). L'observation de ce comportement inhabituel des chromosomes nécessite une clarification ultérieure.

Apis cerana / méiose / parthénogenèse / nombre de chromosomes / ouvrière pondeuse

Zusammenfassug - Analyse der Chromosomen der Eier und Ovarien von legenden Arbeitsbienen von Apis cerana F. Die legenden Arbeiterinnen von A cerana verfügen über ein Paar Ovarien mit je 2-12 Ovariolen (Abb 1). In den Chromosomenpräparaten aus den Ovarien und Eiern wurde in den Ovarien die diploide Chromosomenzahl, $2 n=32$, gefunden (Abb 2). Nur in den Eiern wurden verschiedene Stadien der Meiose gefunden. In den Diakinese- und Metaphase I-Stadien wurden 16 Bivalente beobachtet (Abb 3 und 4). Das Vorhandensein von Bivalenten zeigt, daß eine Paarung und Neuverteilung der homologen Chromosomen erfolgt.

In der Anaphase I (Abb 5) bewegen sich die beiden Chromosomensätze, jeder mit 16 Chromosomen, in Richtung der entge- 
gengesetzten Pole. Auch im Stadium der Metaphase II (Abb 6) wurde der haploide Chromosomensatz von $n=16$ festgestellt.

In einigen Zellen waren sogar nur acht Bivalente zu sehen (Abb 7). Diese Beobachtung eines ungewöhnlichen Verhaltens der Chromosomen bedarf jedoch noch weiterer Klärung.

Apis cerana / Meiose / Chromosomenzahl / Parthenogenese / legende Arbeitsbiene

\section{REFERENCES}

Adhira J, Sakagami SF (1958) Zum gegenwärtigen Zuchtzustand der Japanischen Honigbiene in Kyushu, Süd-Japan. Studien Zur Japanischen Honigbiene $A$ indica cerana Fabr II. $Z$ Bienenforsch 4, 87-96

Darlington CD, La Cour LF (1976) The Handling of Chromosomes. Allen and Unwin, London, 3rd edn

Deodikar CB, Thakar CV (1966) Cytogenetics of Indian honey bees and bearing on taxonomic and breeding problems. Indian J Genet 26A, 266-293

Fahrenhorst $H$ (1977) Nachweis übereinstimmender Chromosomenzahlen $(n=16)$ bei allen 4-Apis Arten. Apidologie 8, 98-100

Hoshiba H, Kusanagi A (1978) Karyological study of honey bee. J Apic Res 17 (3), 105-109

Kapil RP (1962) Anatomy and histology of the female reproductive system of Apis indica. Insectes Soc 9, 145-153
Kerr WE, Silveira ZV (1972) Karyotypic evolution of the bees and corresponding taxonomic implications. Evolution 26, 197-202

Kitzmiller JB, Clark GL (1952) Salivary gland chromosomes in Culex mosquito. Genetics 37,36

Nachtsheim H (1913) Cytologische Studien über die Geschlechtsbestimmung bei der Honigbiene ( $A$ mellifera L). Arch Zellforsch 11, 170239

Naim M, Phadke KG, Rao PJ (1985) Morphometrics and some behavioural species of Apis cerana indica workers under queenless colony condition. Indian J Entomol 47, 179192

Ruttner F (1976) The Cape bee - A biological curiosity. Proc Apimondia Int Symp African bees. Taxonomy Biology and Economic Use (Fletcher DJC, ed) Apimondia, Pretoria, 127131

Sato M, One M, Shimanuki S (1984) Notes on laying workers in the Japanese honey bee Apis cerana japonica with special reference to the number of ovarioles. Honey Bee Science 5 (1), 1-6 (in Japanese)

Tokuda $Y$ (1924) Studies on honey bee with special reference to the Japanese honeybee. Tr Sapporo Nat Hist Soc 9, 1-6

Verma $S$ (1988) Chromosomal analysis of mitotic and meiotic divisies in four species of genus Apis (honey bees). Int Symp Recent Adv Cytogenetic Res. Kurukshetra (India), 26-28 Feb 1988, (abst), p 100

Verma S, Ruttner F (1983) Cytological analysis of the thelytokous parthenogenesis in the Cape honeybee (Apis melifera capensis Escholtz). Apidologie 14, 41-57 